\title{
Association of rs5888 SNP in the scavenger receptor class $B$ type 1 gene and serum lipid levels
}

Dong-Feng Wu' ${ }^{1}$, Rui-Xing Yin ${ }^{1 *}$, Xi-Jiang Hu${ }^{1}$, Lynn Htet Htet Aung ${ }^{1}$, Xiao-Li Cao ${ }^{1}$, Lin Miao ${ }^{1}$, Qing Li ${ }^{1}$, Ting-Ting Yan', Jin-Zhen $\mathrm{Wu}^{1}$ and Shang-Ling Pan ${ }^{2}$

\begin{abstract}
Background: Bai Ku Yao is a special subgroup of the Yao minority in China. The present study was undertaken to detect the association of rs5888 single nucleotide polymorphism (SNP) in the scavenger receptor class B type 1 (SCARB1) gene and several environmental factors with serum lipid levels in the Guangxi Bai Ku Yao and Han populations.

Methods: A total of 598 subjects of Bai Ku Yao and 585 subjects of Han Chinese were randomly selected from our stratified randomized cluster samples. Genotypes of the SCARB1 rs5888 SNP were determined by polymerase chain reaction and restriction fragment length polymorphism combined with gel electrophoresis, and then confirmed by direct sequencing.

Results: The levels of total cholesterol (TC), high-density lipoprotein cholesterol (HDL-C), low-density lipoprotein cholesterol (LDL-C), apolipoprotein (Apo) Al were lower but ApoB was higher in Bai Ku Yao than in Han $(P<0.05-$ 0.001). The frequencies of $\mathrm{C}$ and $\mathrm{T}$ alleles were $78.3 \%$ and $21.7 \%$ in Bai $\mathrm{Ku} \mathrm{YaO}$, and $73.7 \%$ and $26.3 \%$ in $\mathrm{Han}$ $(P<0.01)$; respectively. The frequencies of CC, CT and $\Pi$ genotypes were $60.0 \%, 36.6 \%$ and $3.4 \%$ in Bai Ku Yao, and 54.2\%, 39.0\% and 6.8\% in Han $(P<0.01)$; respectively. The subjects with $\Pi$ genotype in both ethnic groups had lower HDL-C and ApoAl levels than the subjects with CC or CT genotype ( $P<0.05$ for all). Subgroup analyses showed that the subjects with $\Pi$ genotype in Bai Ku Yao had lower HDL-C and ApoAl levels in males than the subjects with CC or CT genotype $(P<0.05$ for all), and the T allele carriers had higher TC, LDL-C and ApoB levels in females than the $T$ allele noncarriers $(P<0.05$ for all). The participants with $T$ genotype in Han also had a lower tendency of HDL-C and ApoAl levels in males than the participants with CC or CT genotype, but the difference did not reach statistically significant $(P=0.063$ and $P=0.086$; respectively). The association of serum $\mathrm{HDL}-\mathrm{C}$ and $\mathrm{ApoAl}$ levels and genotypes was confirmed by the multiple linear regression analysis in both ethnic groups. Serum lipid parameters were also correlated with several environmental factors.
\end{abstract}

Conclusions: The differences in serum lipid levels between the two ethnic groups might partially attribute to the differences in the SCARB1 rs5888 SNP and several environmental factors.

\footnotetext{
* Correspondence: yinruixing@yahoo.com.cn

'Department of Cardiology, Institute of Cardiovascular Diseases, the First Affiliated Hospital, Guangxi Medical University, 22 Shuangyong Road,

Nanning, 530021Guangxi, People's Republic of China

Full list of author information is available at the end of the article
} 


\section{Introduction}

Coronary heart disease (CHD) remains a major cause of worldwide morbidity and mortality despite therapeutic advances that control many risk factors such as lowdensity lipoprotein cholesterol (LDL-C) to levels lower than previously possible [1]. Plasma high-density lipoprotein cholesterol (HDL-C) levels are considered as a major determinant of susceptibility to coronary atherosclerosis in the general population [2,3]. A low plasma HDL-C level is the most common lipid abnormality found in families with premature coronary atherosclerosis [2]. Epidemiological studies showed that plasma HDL-C levels are inversely associated with the risk of CHD: an increase of $1 \mathrm{mg} / \mathrm{dl}$ of HDL-C levels is associated with a $2 \%$ to $3 \%$ decrease of the risk for CHD $[4,5]$. The metabolism of HDL-C is complex, with many factors influencing its circulating plasma levels, both genetic and non-genetic. It has been reported that variation in HDL-C levels is at least $50 \%$ genetically determined [6]. A number of variants in candidate genes have been implicated in the regulation of plasma HDL-C levels $[7,8]$.

The scavenger receptor class B type 1 (SCARB1) is the HDL receptor which binds HDL-C with high affinity. It is expressed primarily in liver and nonplacental steroidogenic tissues and mediates selective cholesterol uptake of HDL by a mechanism distinct from the classic LDL-C receptor pathway, and plays an important role in reverse cholesterol translation (RCT) [9]. In mouse models, studies have clearly demonstrated the crucial role of SCARB1 gene in HDL-C metabolism. Hepatic overexpression of SCARB1 markedly reduced HDL-C and apolipoprotein (Apo) AI levels, and increased biliary cholesterol [10]. In contrast, targeted disruption of the SCARB1 gene in mice reduced selective uptake of cholesterol ester from HDL into the liver and significantly increased plasma HDL-C [11,12]. As a multilipoprotein receptor, SCARB1 also regulates the concentrations of LDL-C and very-low-density lipoprotein (VLDL-C) $[13,14]$. Mice with hepatic overexpression of SCARB1 have lower concentrations of VLDL and LDL $[15,16]$. Conversely, mice with attenuated expression of SCARB1 display elevated concentration of LDL-C [17]. Despite the obvious functional evidence for an influence of SCARB1 on altered serum lipid profile in animal models, it remains to be determined whether this receptor has an equally important function in humans.

The human SCARB1 gene encodes a 509 amino acid protein with a molecular weight of $82 \mathrm{kDa}$ [13] and located on chromosome 12q24, a region showing significant linkage to plasma HDL-C levels [18]. Previous studies have investigated the relationship between variants in the SCARB1 gene and alterations on serum lipid profile in diverse human populations [19-24]. The single nucleotide polymorphism (SNP) of rs5888, a "C" to "T" substitution at amino acid 350 in exon 8 , has been associated with the lipid concentrations of HDL-C $[19,21,23,24]$ and LDL-C $[20,21,23]$. The C allelic frequency of SCARB1 rs5888 was varied from $40 \%$ to $60 \%$ in white population [19-23]. However, in Korean subjects the $\mathrm{C}$ allelic frequency of SCARB1 rs5888 was $67 \%$ in control and $83 \%$ in CHD [24]. These studies suggest that the polymorphism of SCARB1 rs5888 might be different among diverse ethnic groups. Thus, the SCARB1 rs5888 polymorphism in other racial groups still needs to be determined [24].

China is a multi-ethnic country. There are 56 ethnic groups. Han is the largest ethnic group and Yao is the eleventh largest minority among the 55 minority groups according to the population size. Bai Ku Yao (Whitetrouser Yao), an isolated branch of the Yao minority, is named so because all of the men wear white knee-length knickerbockers. The population size is about 30000 . Because of isolation from the other ethnic groups, the special customs and cultures including their clothing, intraethnic marriages, dietary habits, and corn wine and rum intakes are still completely preserved to the present day. They are currently in a transitional period from the matriarchal society to patriarchal society. In several previous epidemiological studies, we showed that several serum lipid phenotypes were lower in Bai Ku Yao than in Han Chinese from the same region $[25,26]$. This ethnic difference in serum lipid profiles is still not well known. We hypothesized that some genetic factors may be different between the two ethnic groups. The SNP of rs5888 in SCARB1 gene had not been discussed in the Chinese population. The aim of the present study was to determine the association of SCARB1 rs5888 SNP and several environmental factors with serum lipid levels in the Guangxi Bai Ku Yao and Han populations.

\section{Materials and methods Study population}

This study included 598 subjects of Bai Ku Yao who reside in Lihu and Baxu villages in Nandan County, Guangxi Zhuang Autonomous Region, People's Republic of China and 585 subjects of Han Chinese reside in the same villages. The subjects of Bai Ku Yao consisted of $286(47.8 \%)$ males and $312(52.2 \%)$ females, ranged in age from 16 to 80 years, with a mean age of $40.22 \pm 15.18$ years. The subjects of Han consisted of 277 (47.4\%) males and 308 (52.6\%) females, aged 16-92 years, with a mean age of $41.87 \pm 16.35$ years. All of the subjects were randomly selected from our previous stratified randomized cluster samples $[25,26]$. The study subjects were healthy rural agricultural workers and without evidence of any chronic illness, including hepatic, renal, or thyroid. The participants with a history of heart attack 
or myocardial infarction, stroke, congestive heart failure, diabetes have been excluded. The participants were not on any lipid-lowering treatment. The present study was approved by the Ethics Committee of the First Affiliated Hospital, Guangxi Medical University. Informed consent was obtained from all subjects after they received a full explanation of the study.

\section{Epidemiological survey}

The survey was carried out using internationally standardized methods [27]. Information on demographics, socioeconomic status, and lifestyle factors were collected with standardized questionnaires. The alcohol information included questions about the number of liangs (about $50 \mathrm{~g}$ ) of rice wine, corn wine, rum, beer, or liquor consumed during the preceding 12 months. At the physical examination, several parameters such as height, weight, and waist circumference were measured. Sitting blood pressure was measured using a mercury sphygmomanometer on 3 separated intervals after the subjects had a 5-minute rest, and the average of the three measurements was used for the level of blood pressure. Body mass index (BMI) was calculated as weight in $\mathrm{kg}$ divided by the square of height in meters $\left(\mathrm{kg} / \mathrm{m}^{2}\right)$.

\section{Biochemical analysis}

Venous blood samples were obtained from all subjects after at least 12 hours of fasting. The levels of serum TC, triglyceride (TG), HDL-C, and LDL-C in samples were determined by enzymatic methods with commercially available kits. Serum ApoAI and ApoB levels were detected by the immunoturbidimetric immunoassay using a commercial kit $[25,26]$.

\section{DNA amplification and genotyping}

Genomic DNA was extracted from peripheral blood leukocytes using the phenol-chloroform method [28]. Genotyping of the SCARB1 rs5888 SNP was performed by polymerase chain reaction and restriction fragment length polymorphism (PCR-RFLP). A pair of primers was designed to introduce a HinI1 restriction site (GACGCC) by changing a base from A to G. Forward 5'CCTTGTTTCTCTCCCATCCTCACTTCCTCGACGC-3', Reverse primer 5'-CACCACCCCAGCCCACAGCAGC-3' (Sangon, Shanghai, People's Republic of China). Each $20 \mu \mathrm{L}$ PCR reaction mixture consisted of $1 \mu \mathrm{L}$ of genomic DNA, $0.5 \mu \mathrm{L}$ of each primer (10 pmol/L), $10 \mu \mathrm{L}$ of $2 \times$ Taq PCR Mastermix (constituent: $20 \mathrm{mM}$ Tris-HCl, pH 8.3, $100 \mathrm{mM} \mathrm{KCl}, 3 \mathrm{mM} \mathrm{MgCl}_{2}, 0.1 \mathrm{U}$ Taq Polymerase/ $\mu \mathrm{L}$, $500 \mu \mathrm{M}$ dNTP each; Tiangen, Beijing, People's Republic of China), and $8 \mu \mathrm{L}$ of $\mathrm{ddH}_{2} \mathrm{O}$ (DNase/RNase-free). The reaction mixture was subjected to denaturation at $95^{\circ} \mathrm{C}$ for $5 \mathrm{~min}$, followed by 33 cycles at $95^{\circ} \mathrm{C}$ for $45 \mathrm{~s}, 71.5^{\circ} \mathrm{C}$ for $30 \mathrm{~s}, 72^{\circ} \mathrm{C}$ for $50 \mathrm{~s}$, then by a final extension at $72^{\circ} \mathrm{C}$ for
$8 \mathrm{~min}$. The quality of PCR products was controlled by electrophoresis on $2 \%$ agarose gel and visualized with ethidium-bromide staining ultraviolet illumination. Then $5 \mu \mathrm{L}$ of amplification products were digested at $37^{\circ} \mathrm{C}$ overnight with $5 \mathrm{U}$ of HinI1 restriction enzyme (Fermentas Co. Canada). After restriction enzyme digestion of the amplified DNA, the fragments were separated by electrophoresis on 3\% agarose gels stained with ethidium bromide, photographed in ultraviolet light. Genotypes were scored by an experienced reader blinded to epidemiological data and serum lipid levels. Six samples (CC, CT and TT genotypes in two; respectively) detected by the PCR-RFLP were also confirmed by direct sequencing.

\section{Diagnostic criteria}

The normal values of serum TC, TG, HDL-C, LDL-C, ApoAI, ApoB levels, and the ratio of ApoAI to ApoB in our Clinical Science Experiment Center were 3.10-5.17, 0.56-1.70, 0.91-1.81, 2.70-3.20 mmol/L, 1.00-1.78, 0.63$1.14 \mathrm{~g} / \mathrm{L}$, and 1.00-2.50; respectively[25,26]. Hypertension was diagnosed according to the criteria of 1999 World Health Organization-International Society of Hypertension Guidelines for the management of hypertension [29]. Normal weight, overweight and obesity were defined as a BMI $<24,24-28$, and $>28 \mathrm{~kg} / \mathrm{m}^{2}$; respectively $[25,26]$.

\section{Statistical analyses}

Epidemiological data were recorded on a pre-designed form and managed with Excel software. All statistical analyses were carried out using the statistical software package SPSS 13.0 (SPSS Inc., Chicago, Illinois). Qualitative variables were expressed as raw count and percentage. Mean \pm standard deviation was used for the presentation of quantitative variables. Genotypic and allelic frequencies were calculated by direct counting, the Hardy-Weinberg equilibrium (HWE) was tested by chisquare, using the observed genotypic frequencies obtained from the data and expected genotypic frequency obtained using the HWE. A chi-square analysis was also used to evaluate the difference in genotype distribution and sex ratio between the groups. The difference in general characteristics between Bai $\mathrm{Ku}$ Yao and Han was tested by the Student's unpaired $t$-test. The association of genotypes and serum lipid parameters was tested by analysis of covariance (ANCOVA). Sex, age, BMI, blood pressure, alcohol consumption, cigarette smoking were adjusted for the statistical analysis. All significant associations were corrected for multiple testing by applying a Bonferroni correction. In order to evaluate the association of serum lipid levels with genotypes $(\mathrm{CC}=1, \mathrm{CT}=2, \mathrm{TT}=3)$ and several environment factors, multiple linear regression analysis with stepwise modeling was also performed in the combined population of 
Table 1 The general characteristics and serum lipid levels

\begin{tabular}{|c|c|c|c|c|}
\hline Parameter & Bai Ku Yao & Han Chinese & $t\left(x^{2}\right)$ & $P$ \\
\hline Number & 598 & 585 & - & - \\
\hline Male/female & $286 / 312$ & $277 / 308$ & 0.027 & 0.870 \\
\hline Age (years) & $40.22 \pm 15.18$ & $41.87 \pm 16.35$ & -1.795 & 0.073 \\
\hline Height (cm) & $152.64 \pm 7.37$ & $156.33 \pm 7.90$ & -8.318 & 0.000 \\
\hline Weight (kg) & $51.69 \pm 7.23$ & $54.57 \pm 9.74$ & -5.742 & 0.000 \\
\hline Body mass index $\left(\mathrm{kg} / \mathrm{m}^{2}\right)$ & $22.15 \pm 2.38$ & $22.29 \pm 3.46$ & -0.814 & 0.416 \\
\hline Systolic blood pressure $(\mathrm{mmHg})$ & $119.26 \pm 17.44$ & $122.78 \pm 18.76$ & -3.352 & 0.001 \\
\hline Diastolic blood pressure $(\mathrm{mmHg})$ & $75.46 \pm 9.69$ & $77.58 \pm 11.52$ & -3.430 & 0.001 \\
\hline Pulse pressure $(\mathrm{mmHg})$ & $43.80 \pm 13.23$ & $45.20 \pm 12.79$ & -1.855 & 0.064 \\
\hline \multicolumn{5}{|l|}{ Cigarette smoking [n (\%)] } \\
\hline Nonsmoker & $414(69.2)$ & $437(74.7)$ & & \\
\hline$<20$ cigarettes/day & $84(14.0)$ & $57(9.7)$ & & \\
\hline$\geq 20$ cigarettes/day & $100(16.7)$ & $91(15.6)$ & 6.074 & 0.048 \\
\hline \multicolumn{5}{|l|}{ Alcohol consumption [n (\%)] } \\
\hline Nondrinker & $329(55.0)$ & $458(78.3)$ & & \\
\hline$<25$ g/day & $172(28.8)$ & $80(13.7)$ & 71.959 & 0.000 \\
\hline$\geq 25 \mathrm{~g} /$ day & $97(16.2)$ & $47(8.0)$ & & \\
\hline Total cholesterol (mmol/L) & $4.35 \pm 0.92$ & $4.71 \pm 0.99$ & -6.551 & 0.000 \\
\hline Triglyceride (mmol/L) & $1.00(0.65)$ & $1.00(0.79)$ & -1.734 & 0.083 \\
\hline $\mathrm{HDL}-\mathrm{C}(\mathrm{mmol} / \mathrm{L})$ & $1.67 \pm 0.42$ & $1.73 \pm 0.46$ & -2.431 & 0.015 \\
\hline LDL-C (mmol/L) & $2.57 \pm 0.76$ & $2.72 \pm 0.79$ & -3.502 & 0.000 \\
\hline Apolipoprotein (Apo) Al (g/L) & $1.31 \pm 0.32$ & $1.35 \pm 0.31$ & -2.110 & 0.035 \\
\hline ApoB (g/L) & $0.85 \pm 0.23$ & $0.82 \pm 0.20$ & 2.314 & 0.021 \\
\hline ApoAl/ApoB & $1.67 \pm 0.75$ & $1.73 \pm 0.53$ & -1.382 & 0.167 \\
\hline
\end{tabular}

HDL-C, high-density lipoprotein cholesterol; LDL-C, low-density lipoprotein cholesterol. The value of triglyceride was presented as median (interquartile range). The difference between the two ethnic groups was determined by the Wilcoxon-Mann-Whitney test.

Bai $\mathrm{Ku}$ Yao and Han, Bai $\mathrm{Ku}$ Yao, Han, males and females; respectively. A two-tailed $P$ value less than 0.05 was considered statistically significant.

\section{Results}

\section{General characteristics and serum lipid levels}

The general characteristics and serum lipid levels between the Bai Ku Yao and Han populations are summarized in Table 1. As comparison with the population of Han, Bai Ku Yao has lower levels of height, weight, systolic blood pressure, diastolic blood pressure, serum TC, HDL-C, LDL-C, ApoAI, and higher serum ApoB levels, percentages of subjects who consumed alcohol or smoked cigarettes $(P<0.05-0.001)$. There were no significant differences in the levels of BMI, pulse pressure, serum TG, the ratio of ApoAI to ApoB, age structure, or the ratio of male to female between the two ethnic groups $(P>0.05$ for all $)$.

\section{Results of electrophoresis and genotyping}

After the genomic DNA of the samples was amplified by PCR and imaged by $2.0 \%$ agarose gel electrophoresis, the
PCR products of $218 \mathrm{bp}$ nucleotide sequences could be found in all samples (Figure 1). The genotypes identified were named according to the presence or absence of the enzyme restriction sites, when a $\mathrm{C}$ to $\mathrm{T}$ transversion at amino acid 350 of the SCARB1 gene. The presence of the cutting site indicates the $\mathrm{C}$ allele, while its absence indicates the T allele (cannot be cut). Thus, the TT genotype is homozygote for the absence of the site (band at $218 \mathrm{bp}), \mathrm{CT}$ genotype is heterozygote for the absence and presence of the site (bands at 218-, 187- and 31-bp), and CC genotype is homozygote for the presence of the site (bands at 187- and 31-bp; Figure 2). The 31 bp fragment was invisible in the gel owing to its fast migration speed.

\section{Genotypic and allelic frequencies}

The genotypic and allelic frequencies of SCARB1 rs5888 SNP are shown in Table 2. The frequency of $\mathrm{C}$ and $\mathrm{T}$ alleles was $78.3 \%$ and $21.7 \%$ in Bai $\mathrm{Ku}$ Yao, and $73.7 \%$ and $26.3 \%$ in Han $(P<0.01)$; respectively. The frequency of CC, CT and TT genotypes was $60.0 \%, 36.6 \%$ and $3.3 \%$ 


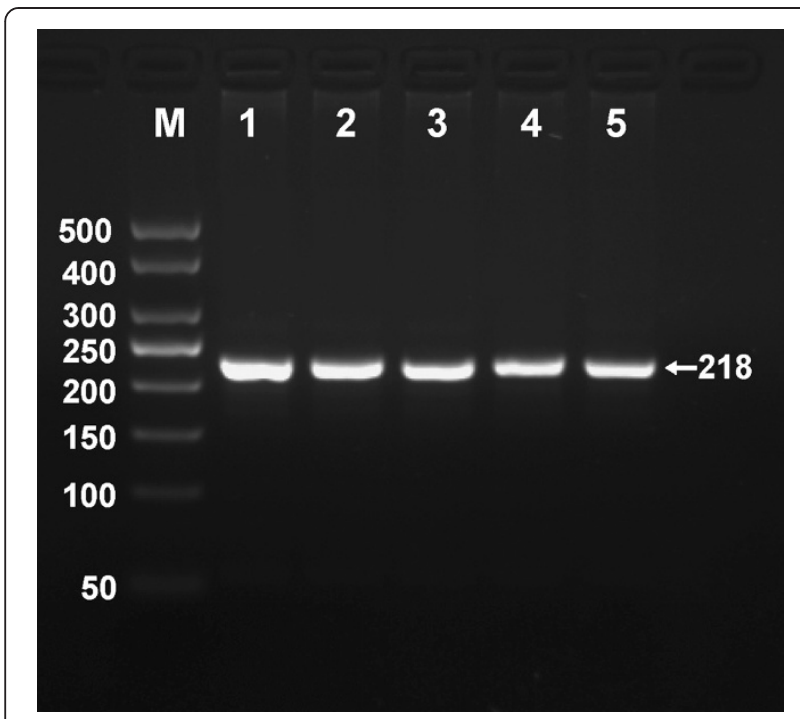

Figure 1 Electrophoresis of PCR products of the samples. Lane M, 50 bp marker ladder; lanes 1-5, samples. The 218 bp bands are the PCR products.

in Bai $\mathrm{Ku}$ Yao, and $54.2 \%, 39.0 \%$ and $6.8 \%$ in Han $(P$ $<0.01)$; respectively. There was no significant difference in the genotypic and allelic frequencies between males and females in both ethnic groups.

\section{Results of sequencing}

The results were shown as CC, CT and TT genotypes by PCR-RFLP, the CC, CT and TT genotypes were also confirmed by sequencing (Figure 3); respectively.

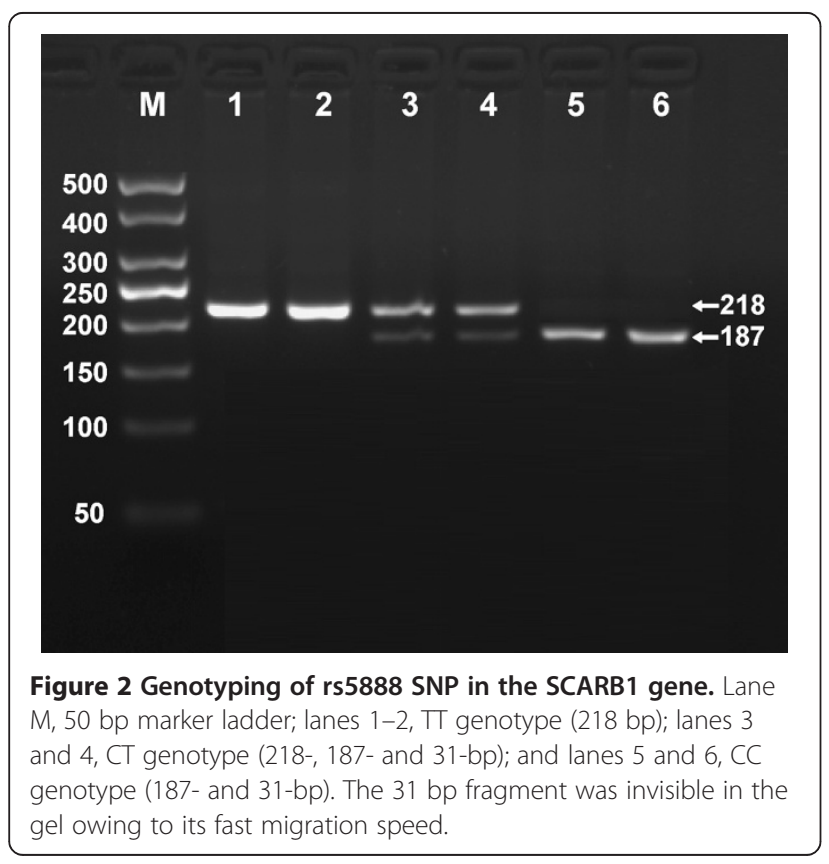

\section{Genotypes and serum lipid levels}

As shown in Table 3, the levels of HDL-C and ApoAI in the Bai $\mathrm{Ku}$ Yao and Han subjects were different among the three genotypes $(P<0.05$ for all), the subjects with TT genotype had lower serum HDL-C and ApoAI levels than the subjects with CT or CC genotype. When analysis of covariance was stratified according to sex in both ethnic groups, we found that the subjects with TT genotype in Bai $\mathrm{Ku}$ Yao had lower HDL-C and ApoAI levels in males than the subjects with $\mathrm{CC}$ or $\mathrm{CT}$ genotype ( $P$ $<0.05$ for all), and the $\mathrm{T}$ allele carriers had higher $\mathrm{TC}$, LDL-C and ApoB levels in females than the T allele noncarriers $(P<0.05$ for all). The participants with TT genotype in Han also had a lower tendency of HDL-C and ApoAI levels in males than the participants with $\mathrm{CC}$ or CT genotype, but the difference did not reach statistically significant $(P=0.063$ and $P=0.086$; respectively).

\section{Relative factors for serum lipid parameters}

Multiple linear regression analysis showed that serum HDL-C and ApoAI levels were correlated with genotypes in the combined populations of Bai $\mathrm{Ku}$ Yao and Han, Bai Ku Yao, and Han; respectively ( $P<0.05$ for all). When multiple linear regression analysis was performed according to sex in both ethnic groups, we found that the levels of HDL-C and ApoAI in Bai Ku Yao were correlated with genotypes in males $(P<0.05$ for each, Table 4) but not in females. The levels of TC and LDL-C in Bai $\mathrm{Ku}$ Yao were also associated with genotypes in females but not in males. The levels of TG and HDL-C in Han were correlated with genotypes in males $(P$ $<0.05$ for each). Serum lipid parameters were also correlated with sex, age, BMI, alcohol consumption, cigarette smoking, and blood pressure in both ethnic groups (Tables 5 and 4).

\section{Discussion}

The current study shows that the levels of serum TC, HDL-C, LDL-C, ApoAI were lower, whereas the levels of ApoB was higher in Bai $\mathrm{Ku}$ Yao than in Han. There was no significant difference in the levels of TG and the ratio of ApoAI to ApoB between the two ethnic groups. It is well known that dyslipidemia is a complex trait caused by both environmental and genetic factors. Bai $\mathrm{Ku}$ Yao is an isolated subgroup of the Yao minority in China. Strict intra-ethnic marriages have been performed in this population from time immemorial. Therefore, we are confident that the hereditary characteristics and genotypes of some lipid metabolism-related genes in this population may be different from those in Han Chinese.

In the present study, we showed that there was significant difference in the allelic and genotypic frequencies of SCARB1 rs5888 SNP between the two ethnic groups. 
Table 2 The genotype and allele frequencies of the SCARB1 rs5888 SNP [n (\%)]

\begin{tabular}{|c|c|c|c|c|c|c|}
\hline \multirow[t]{2}{*}{ Group } & \multirow[t]{2}{*}{$n$} & \multicolumn{3}{|l|}{ Genotype } & \multicolumn{2}{|l|}{ Allele } \\
\hline & & $\overline{C C}$ & $\mathrm{CT}$ & $\mathrm{TT}$ & $\bar{C}$ & $\mathbf{T}$ \\
\hline Bai Ku Yao & 598 & $359(60.0)$ & 219 (36.6) & $20(3.4)$ & 937 (78.3) & $259(21.7)$ \\
\hline Han Chinese & 585 & $317(54.2)$ & $228(39.0)$ & $40(6.8)$ & $862(73.7)$ & $308(26.3)$ \\
\hline$x^{2}$ & - & 9.316 & & & 7.076 & \\
\hline P & - & 0.009 & & & 0.008 & \\
\hline \multicolumn{7}{|l|}{ Bai Ku Yao } \\
\hline Male & 286 & $176(61.5)$ & 99 (34.6) & $11(3.8)$ & $451(78.8)$ & $121(21.2)$ \\
\hline Female & 312 & $183(58.7)$ & $120(38.5)$ & $9(2.9)$ & $486(77.9)$ & $138(22.1)$ \\
\hline$x^{2}$ & - & 1.222 & & & 0.163 & \\
\hline P & - & 0.543 & & & 0.687 & \\
\hline \multicolumn{7}{|l|}{ Han Chinese } \\
\hline Male & 277 & 145 (52.3) & $114(41.2)$ & $18(6.5)$ & $404(72.9)$ & $150(27.1)$ \\
\hline Female & 308 & $172(55.8)$ & $114(37.0)$ & $22(7.1)$ & $458(74.4)$ & 158 (25.6) \\
\hline$x^{2}$ & - & 1.060 & & & 0.306 & \\
\hline P & - & 0.589 & & & 0.580 & \\
\hline
\end{tabular}

The frequencies of CC genotypes were higher in Bai $\mathrm{Ku}$ Yao than in Han. The frequency of $\mathrm{C}$ allele was also higher in Bai $\mathrm{Ku}$ Yao than in Han $(78.3 \%$ vs $73.7 \%$,
$P<0.01)$. To the best of our knowledge, this is the first study to report the association of SCARB1 rs5888 SNP and serum lipid levels in the Bai Ku Yao population. The
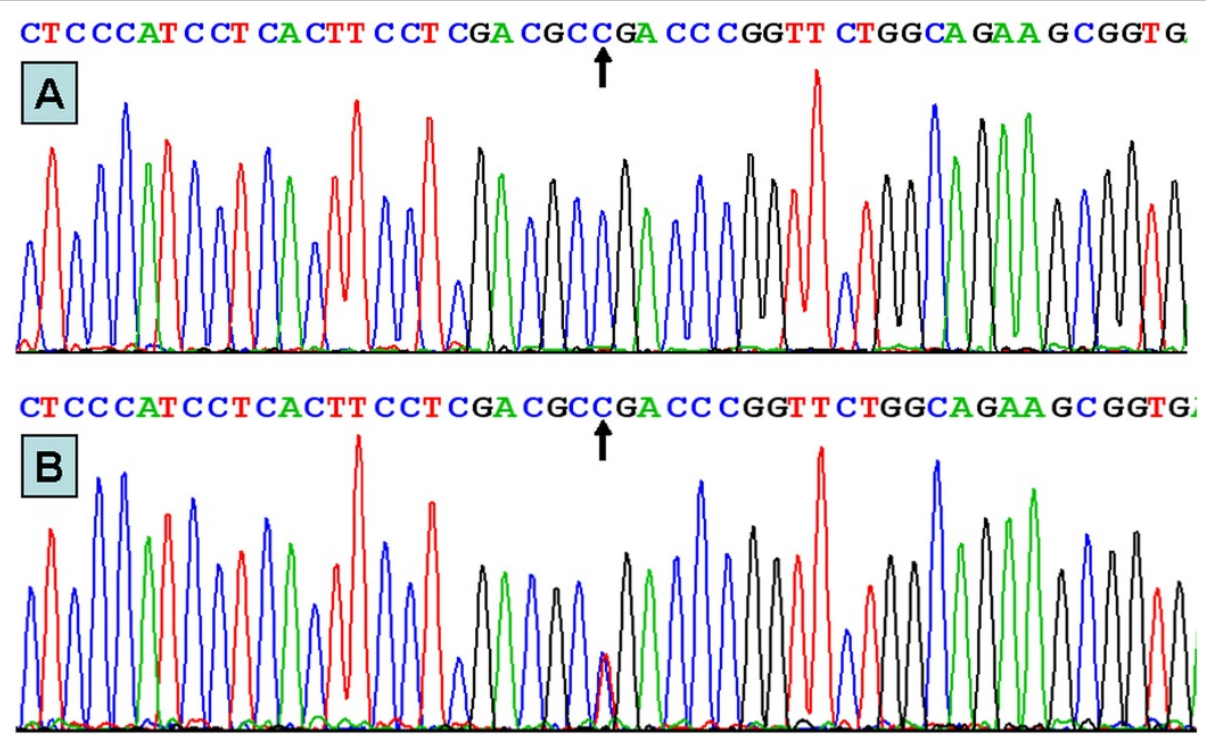

CT C C CAT C CT CACT T C CT CGA CGCTGA C C CGT T CTGGCAGAA G CGGT G:

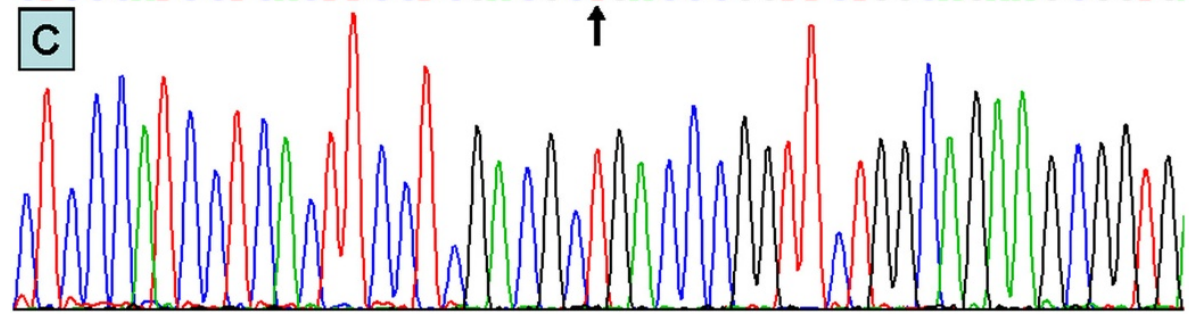

Figure 3 A part of the nucleotide sequence of rs5888 SNP in the SCARB1 gene. (A) CC genotype; (B) CT genotype; (C) TT genotype. 
Table 3 The genotypes of SCARB1 rs5888 SNP and serum lipid levels

\begin{tabular}{|c|c|c|c|c|c|c|c|c|}
\hline Genotype & $\mathrm{n}$ & $\mathrm{TC}(\mathrm{mmol} / \mathrm{L})$ & $\mathrm{TG}(\mathrm{mmol} / \mathrm{L})$ & HDL-C (mmol/L) & LDL-C (mmol/L) & ApoAl (g/L) & ApoB (g/L) & ApoAl/ApoB \\
\hline \multicolumn{9}{|l|}{ Bai Ku Yao } \\
\hline CC & 359 & $4.30 \pm 0.94$ & $0.98(0.69)$ & $1.66 \pm 0.42^{a}$ & $2.54 \pm 0.76$ & $1.31 \pm 0.32^{a}$ & $0.84 \pm 0.23$ & $1.68 \pm 0.76$ \\
\hline$C T$ & 219 & $4.44 \pm 0.89$ & $1.02(0.62)$ & $1.69 \pm 0.41^{a}$ & $2.64 \pm 0.75$ & $1.33 \pm 0.33^{\mathrm{a}}$ & $0.87 \pm 0.22$ & $1.67 \pm 0.72$ \\
\hline$\pi$ & 20 & $4.04 \pm 0.96$ & $1.10(0.52)$ & $1.43 \pm 0.36$ & $2.42 \pm 0.88$ & $1.14 \pm 0.27$ & $0.78 \pm 0.27$ & $1.66 \pm 1.00$ \\
\hline$F$ & - & 2.770 & 0.388 & 4.001 & 1.625 & 3.878 & 1.871 & 0.023 \\
\hline$P$ & - & 0.063 & 0.824 & 0.019 & 0.198 & 0.021 & 0.155 & 0.977 \\
\hline \multicolumn{9}{|l|}{ Male } \\
\hline CC & 176 & $4.39 \pm 1.09$ & $1.18(0.95)$ & $1.70 \pm 0.49^{\mathrm{a}}$ & $2.54 \pm 0.92$ & $1.38 \pm 0.37^{a}$ & $0.83 \pm 0.23$ & $1.82 \pm 0.95$ \\
\hline$C T$ & 99 & $4.43 \pm 1.01$ & $1.05(0.69)$ & $1.74 \pm 0.46^{b}$ & $2.55 \pm 0.86$ & $1.39 \pm 0.40^{a}$ & $0.83 \pm 0.23$ & $1.86 \pm 0.92$ \\
\hline$\pi$ & 11 & $3.97 \pm 1.07$ & $1.25(0.61)$ & $1.30 \pm 0.45$ & $2.35 \pm 0.99$ & $1.10 \pm 0.35$ & $0.76 \pm 0.30$ & $1.74 \pm 1.32$ \\
\hline$F$ & - & 0.985 & 1.822 & 4.743 & 0.253 & 3.769 & 0.559 & 0.117 \\
\hline P & - & 0.375 & 0.402 & 0.009 & 0.776 & 0.024 & 0.572 & 0.889 \\
\hline CC & 176 & $4.39 \pm 10.9$ & $1.18(0.95)$ & $1.70 \pm 0.49$ & $2.54 \pm 0.92$ & $1.38 \pm 0.37$ & $0.83 \pm 0.23$ & $1.82 \pm 0.95$ \\
\hline$C T+\pi$ & 110 & $4.38 \pm 1.02$ & $1.06(0.65)$ & $1.70 \pm 0.47$ & $2.53 \pm 0.87$ & $1.36 \pm 0.40$ & $0.82 \pm 0.24$ & $1.85 \pm 0.96$ \\
\hline$F$ & - & 0.003 & -1.246 & 0.024 & 0.014 & 0.222 & 0.106 & 0.072 \\
\hline P & - & 0.959 & 0.213 & 0.877 & 0.907 & 0.638 & 0.745 & 0.788 \\
\hline \multicolumn{9}{|l|}{ Female } \\
\hline CC & 183 & $4.22 \pm 0.76$ & $0.90(0.51)$ & $1.63 \pm 0.33$ & $2.53 \pm 0.58$ & $1.24 \pm 0.25$ & $0.84 \pm 0.22$ & $1.56 \pm 0.48$ \\
\hline$C T$ & 120 & $4.45 \pm 0.78^{c}$ & $1.00(0.61)$ & $1.65 \pm 0.35$ & $2.72 \pm 0.64^{c}$ & $1.27 \pm 0.25$ & $0.90 \pm 0.19$ & $1.49 \pm 0.44$ \\
\hline$\pi$ & 9 & $4.19 \pm 0.84$ & $1.05(0.38)$ & $1.51 \pm 0.24$ & $2.57 \pm 0.74$ & $1.16 \pm 0.16$ & $0.84 \pm 0.24$ & $1.46 \pm 0.31$ \\
\hline F & - & 3.562 & 2.102 & 0.655 & 3.881 & 1.198 & 2.601 & 1.121 \\
\hline P & - & 0.030 & 0.350 & $0.520^{`}$ & 0.022 & 0.303 & 0.076 & 0.327 \\
\hline CC & 183 & $4.22 \pm 0.76$ & $0.90(0.51)$ & $1.63 \pm 0.33$ & $2.53 \pm 0.58$ & $1.24 \pm 0.25$ & $0.84 \pm 0.22$ & $1.56 \pm 0.48$ \\
\hline$C T+T T$ & 129 & $4.43 \pm 0.78$ & $1.01(0.60)$ & $1.64 \pm 0.34$ & $2.71 \pm 0.65$ & $1.26 \pm 0.24$ & $0.89 \pm 0.20$ & $1.48 \pm 0.44$ \\
\hline F & - & 6.103 & -1.429 & 0.054 & 7.234 & 0.542 & 4.473 & 2.224 \\
\hline$P$ & - & 0.014 & 0.153 & 0.817 & 0.008 & 0.462 & 0.035 & 0.137 \\
\hline \multicolumn{9}{|c|}{ Han Chinese } \\
\hline $\mathrm{CC}$ & 317 & $4.73 \pm 0.96$ & $0.97(0.82)$ & $1.76 \pm 0.49^{a}$ & $2.75 \pm 0.76$ & $1.36 \pm 0.31^{a}$ & $0.82 \pm 0.19$ & $1.74 \pm 0.54$ \\
\hline$C T$ & 228 & $4.71 \pm 1.01$ & 1.05 (0.78) & $1.72 \pm 0.44^{\mathrm{a}}$ & $2.73 \pm 0.85$ & $1.35 \pm 0.31^{a}$ & $0.82 \pm 0.21$ & $1.74 \pm 0.54$ \\
\hline$\pi$ & 40 & $4.54 \pm 1.05$ & $0.99(0.97)$ & $1.55 \pm 0.35$ & $2.58 \pm 0.67$ & $1.23 \pm 0.21$ & $0.81 \pm 0.18$ & $1.56 \pm 0.35$ \\
\hline$F$ & - & 0.821 & 1.764 & 4.125 & 0.965 & 3.824 & 0.044 & 2.313 \\
\hline$P$ & - & 0.441 & 0.414 & 0.017 & 0.381 & 0.022 & 0.957 & 0.100 \\
\hline \multicolumn{9}{|l|}{ Male } \\
\hline CC & 145 & $4.73 \pm 0.94$ & $1.11(0.89)$ & $1.68 \pm 0.54$ & $2.74 \pm 0.72$ & $1.34 \pm 0.36$ & $0.83 \pm 0.18$ & $1.67 \pm 0.50$ \\
\hline$C T$ & 114 & $4.70 \pm 1.07$ & $1.13(0.90)$ & $1.64 \pm 0.39$ & $2.74 \pm 0.91$ & $1.32 \pm 0.32$ & $0.84 \pm 0.23$ & $1.67 \pm 0.54$ \\
\hline$\pi$ & 18 & $4.59 \pm 1.22$ & 1.23 (1.79) & $1.43 \pm 0.26$ & $2.47 \pm 0.65$ & $1.18 \pm 0.18$ & $0.83 \pm 0.20$ & $1.49 \pm 0.37$ \\
\hline F & - & 0.233 & 1.500 & 2.793 & 1.070 & 2.474 & 0.036 & 1.160 \\
\hline P & - & 0.793 & 0.472 & 0.063 & 0.344 & 0.086 & 0.965 & 0.315 \\
\hline CC & 145 & $4.73 \pm 0.94$ & $1.11(0.89)$ & $1.68 \pm 0.54$ & $2.74 \pm 0.72$ & $1.34 \pm 0.36$ & $0.83 \pm 0.18$ & $1.67 \pm 0.50$ \\
\hline$C T+\pi$ & 132 & $4.69 \pm 1.09$ & $1.15(0.94)$ & $1.61 \pm 0.38$ & $2.71 \pm 0.88$ & $1.30 \pm 0.30$ & $0.84 \pm 0.22$ & $1.65 \pm 0.52$ \\
\hline$F$ & - & 0.212 & -1.071 & 1.746 & 0.139 & 1.216 & 0.041 & 0.124 \\
\hline P & - & 0.646 & 0.284 & 0.187 & 0.709 & 0.271 & 0.839 & 0.725 \\
\hline \multicolumn{9}{|l|}{ Female } \\
\hline CC & 172 & $4.74 \pm 0.98$ & $0.91(0.80)$ & $1.83 \pm 0.43$ & $2.76 \pm 0.80$ & $1.38 \pm 0.27$ & $0.81 \pm 0.19$ & $1.80 \pm 0.57$ \\
\hline
\end{tabular}


Table 3 The genotypes of SCARB1 rs5888 SNP and serum lipid levels (Continued)

\begin{tabular}{lllllllll}
\hline $\mathrm{CT}$ & 114 & $4.69 \pm 0.94$ & $0.96(0.60)$ & $1.78 \pm 0.48$ & $2.70 \pm 0.78$ & $1.37 \pm 0.31$ & $0.80 \pm 0.19$ & $1.80 \pm 0.53$ \\
$T T$ & 22 & $4.54 \pm 0.91$ & $0.94(0.69)$ & $1.68 \pm 0.38$ & $2.68 \pm 0.69$ & $1.29 \pm 0.23$ & $0.80 \pm 0.15$ & $1.64 \pm 0.34$ \\
$F$ & - & 0.559 & 0.914 & 1.343 & 0.373 & 1.139 & 0.115 & 0.937 \\
$P$ & - & 0.572 & 0.633 & 0.263 & 0.689 & 0.322 & 0.891 & 0.393 \\
$C C$ & 172 & $4.74 \pm 0.98$ & $0.91(0.80)$ & $1.83 \pm 0.43$ & $2.76 \pm 0.80$ & $1.38 \pm 0.27$ & $0.81 \pm 0.19$ & $1.80 \pm 0.57$ \\
$C T+\pi$ & 136 & $4.66 \pm 0.93$ & $0.96(0.60)$ & $1.76 \pm 0.46$ & $2.69 \pm 0.77$ & $1.36 \pm 0.30$ & $0.80 \pm 0.18$ & $1.77 \pm 0.50$ \\
$F$ & & 0.644 & -0.657 & 1.841 & 0.730 & 0.602 & 0.227 & 0.255 \\
$P$ & & 0.423 & 0.511 & 0.176 & 0.394 & 0.439 & 0.634 & 0.614 \\
\hline
\end{tabular}

TC, total cholesterol; TG, triglyceride; HDL-C, high-density lipoprotein cholesterol; LDL-C, low-density lipoprotein cholesterol; ApoAl, apolipoprotein Al; ApoB, apolipoprotein $\mathrm{B}$. The value of TG was presented as median (interquartile range), the difference among the genotypes was determined by the Kruskal-Wallis test or the Wilcoxon-Mann-Whitney test. ${ }^{\mathrm{a}} P<0.05,{ }^{\mathrm{b}} P<0.01$ in comparison with the $\Pi \mathrm{T}$ genotype of the same ethnic group and ${ }^{\mathrm{c}} P<0.05$ in comparison with the $C \mathrm{C}$ genotype of the same ethnic group.

genotypic and allelic frequency of SCARB1 rs5888 SNP in Han population observed in our research was also consistent with the frequency of Han Chinese from Beijing published on NCBI database (http://www.ncbi.nlm. nih.gov/projects/SNP/snp_ref.cgi?rs=5888). Several similar researches have carried out in European and North American populations. In a initial study in Spain population, Acton et al. [20] determined the polymorphism of Exon $8(\mathrm{C} / \mathrm{T})$ (rs5888) and showed that the frequency of $\mathrm{C}$ allele was $56.22 \%$ in a general white Spanish population. In another study, McCarthy et al. [22] reported the frequency of $\mathrm{C}$ allele was $44.7 \%$ in Israeli, $60.2 \%$ in Finn and $52.5 \%$ in Swede; respectively. In an American population of Central European ancestry, the allele frequency of $C$ in the SCARB1 gene was $59.0 \%$ [19]. In a population of Caucasian in America, the frequency of $\mathrm{C}$ allele of rs5888 polymorphism in the SCARB1 gene was $51.39 \%$ in men and women [23]. In Korean subjects, however, the frequency of the common $\mathrm{C}$ allele of SCARB1 HaeIII (rs5888) was 67\% in control and $83 \%$ in CHD [24] which was similar to our study in Chinese population. Thus, our findings, coupled with reports in the literature, provide evidence for the prevalence of the $\mathrm{C}$ allele variation of rs5888 in the SCARB1 gene may have an ethnic specificity.

Several ethnic distinct populations have been previously reported that the T allele of SCARB1 rs5888 is correlated with an increase of serum HDL-C concentration and a decrease of LDL-C concentration. In a population of healthy Spanish, Acton et al. [20] reported that the T allele carriers have significant lower concentration of LDL-C than the $\mathrm{T}$ allele noncarriers in females but not in males. They did not find the association of exons 8 (rs5888) variant in SCARB1 with HDL-C levels. In a population of Caucasian in North America, Osgood et al. [23] showed that the $\mathrm{T}$ allele was associated with an increase in HDL particle size in men and women, serum HDL-C levels in men, and a decrease in LDL-C levels in women. In a cohort of the Amish Family
Diabetes, Roberts et al. [19] documented that the rs5888 variant was significantly associated with higher HDL-C level in women younger than 50 years but not in women aged 50 years or older. In a case-control study including 137 subject with $\mathrm{CHD}$ and 124 age-matched controls, the concentrations of plasma HDL-C and ApoAI varied significantly among HaeIII (rs5888) genotypes in the CHD patients but not in the controls, the common genotype (CC) was associated with a lower concentrations of plasma HDL-C and ApoAI [24]. Morabia et al. [21] also found that the $\mathrm{T}$ allele has higher levels of HDL-C and HDL-C/LDL-C ratio in men. Two other studies carried out by McCarthy et al. [20,30] did not find the single rs5888 variant was correlated with lipid profiles, when combined with other polymorphisms in the SCARB1 gene, the combined genotypes were associated with TG, TG/HDL-C ratio and HDL-C in the women. However, some researches found that the rs5888 $\mathrm{T}$ allele was associated with increased levels of TC, LDL-C and TG. In a research on subjects with heterozygous familial hypercholesterolemia, Tai et al. [31] found that the exon 8 (rs5888) polymorphism was associated with increased levels of TC, VLDL-C, LDL-C and TG. Morabia et al. [21] also showed that the genotype of TT had higher levels of TC and LDL-C than the CC genotype in females.

It is well documented that an overexpression of SCARB1 in the animal model could induce a decreased in the levels of HDL-C, LDL-C, and ApoB $[10,15]$ and mice with attenuated expression of SCARB1 display elevated concentrations of LDL-C as well as HDL-C $[11,12]$. In human, a novel 11-base pair deletion mutation in the promoter region of the SCARB1 gene explained some of the interindividual variation in plasma HDL-C levels in Chinese Taiwanese [32]. A study of women with hyperalphalipoproteinemia also showed that SCARB1 protein was inversely correlated with HDL-C levels and HDL size [33], which suggesting that the SCARB1 in human may partly play the similar role 
Table 4 Correlative factors for serum lipid parameters between males and females

\begin{tabular}{|c|c|c|c|c|c|c|}
\hline Lipid parameter & Relative factor & Unstandardized coefficient & Std. error & Standardized coefficient & $t$ & $P$ \\
\hline \multicolumn{7}{|l|}{ Bai Ku Yao/male } \\
\hline TC & Body mass index & 0.120 & 0.028 & 0.245 & 4.268 & 0.000 \\
\hline TG & Body mass index & 0.112 & 0.033 & 0.200 & 3.436 & 0.001 \\
\hline \multirow[t]{4}{*}{$\mathrm{HDL}-\mathrm{C}$} & Alcohol consumption & 0.192 & 0.036 & 0.304 & 5.274 & 0.000 \\
\hline & Age & 0.006 & 0.002 & 0.189 & 3.302 & 0.001 \\
\hline & Genotype & -0.416 & 0.137 & -0.166 & -3.036 & 0.003 \\
\hline & Body mass index & -0.026 & 0.012 & -0.116 & -2.116 & 0.035 \\
\hline LDL-C & Body mass index & 0.098 & 0.024 & 0.236 & 4.092 & 0.000 \\
\hline \multirow[t]{3}{*}{ ApoAl } & Alcohol consumption & 0.170 & 0.028 & 0.342 & 6.048 & 0.000 \\
\hline & Age & 0.004 & 0.001 & 0.155 & 2.743 & 0.006 \\
\hline & Genotype & -0.287 & 0.107 & -0.145 & -2.690 & 0.008 \\
\hline ApoB & Body mass index & 0.029 & 0.006 & 0.267 & 4.677 & 0.000 \\
\hline \multirow[t]{2}{*}{ ApoAl/ApoB } & Alcohol consumption & 0.376 & 0.071 & 0.301 & 5.274 & 0.000 \\
\hline & Body mass index & -0.069 & 0.025 & -0.157 & -2.752 & 0.006 \\
\hline \multicolumn{7}{|l|}{ Bai Ku Yao/female } \\
\hline \multirow[t]{3}{*}{ TC } & Systolic blood pressure & 0.007 & 0.003 & 0.145 & 2.602 & 0.010 \\
\hline & Body mass index & 0.036 & 0.017 & 0.120 & 2.138 & 0.033 \\
\hline & Genotype & 0.165 & 0.078 & 0.118 & 2.118 & 0.035 \\
\hline TG & Alcohol consumption & 0.311 & 0.079 & 0.219 & 3.961 & 0.000 \\
\hline \multirow[t]{3}{*}{ LDL-C } & Genotype & 0.151 & 0.061 & 0.135 & 2.465 & 0.014 \\
\hline & Body mass index & 0.034 & 0.014 & 0.141 & 2.519 & 0.012 \\
\hline & Age & 0.005 & 0.003 & 0.122 & 1.997 & 0.047 \\
\hline ApoAl & Age & 0.002 & 0.001 & 0.141 & 2.509 & 0.013 \\
\hline \multirow[t]{2}{*}{ ApoB } & Systolic blood pressure & 0.002 & 0.001 & 0.175 & 3.134 & 0.002 \\
\hline & Body mass index & 0.012 & 0.005 & 0.143 & 2.572 & 0.011 \\
\hline ApoAl/ApoB & Diastolic blood pressure & -0.007 & 0.003 & -0.139 & -2.466 & 0.014 \\
\hline \multicolumn{7}{|l|}{ Han/male } \\
\hline \multirow[t]{4}{*}{ TC } & Diastolic blood pressure & 0.019 & 0.005 & 0.227 & 3.783 & 0.000 \\
\hline & Age & 0.013 & 0.003 & 0.239 & 4.243 & 0.000 \\
\hline & Alcohol consumption & 0.249 & 0.071 & 0.186 & 3.494 & 0.001 \\
\hline & Body mass index & 0.031 & 0.015 & 0.120 & 2.108 & 0.036 \\
\hline \multirow[t]{3}{*}{ TG } & Body mass index & 0.119 & 0.021 & 0.320 & 5.729 & 0.000 \\
\hline & Cigarette smoking & 0.282 & 0.092 & 0.172 & 3.069 & 0.002 \\
\hline & Genotype & 0.292 & 0.132 & 0.125 & 2.216 & 0.027 \\
\hline \multirow[t]{5}{*}{$\mathrm{HDL}-\mathrm{C}$} & Alcohol consumption & 0.177 & 0.034 & 0.287 & 5.223 & 0.000 \\
\hline & Age & 0.006 & 0.001 & 0.237 & 4.082 & 0.000 \\
\hline & Body mass index & -0.029 & 0.007 & -0.243 & -4.147 & 0.000 \\
\hline & Diastolic blood pressure & 0.006 & 0.002 & 0.156 & 2.523 & 0.012 \\
\hline & Genotype & -0.082 & 0.041 & -0.108 & -2.011 & 0.045 \\
\hline \multirow[t]{3}{*}{ LDL-C } & Age & 0.009 & 0.003 & 0.210 & 3.450 & 0.001 \\
\hline & Diastolic blood pressure & 0.009 & 0.004 & 0.142 & 2.181 & 0.030 \\
\hline & Body mass index & 0.026 & 0.013 & 0.128 & 2.082 & 0.038 \\
\hline \multirow[t]{2}{*}{ ApoAl } & Alcohol consumption & 0.161 & 0.023 & 0.369 & 6.960 & 0.000 \\
\hline & Age & 0.005 & 0.001 & 0.281 & 5.301 & 0.000 \\
\hline
\end{tabular}


Table 4 Correlative factors for serum lipid parameters between males and females (Continued)

\begin{tabular}{|c|c|c|c|c|c|c|}
\hline \multirow[t]{3}{*}{ ApoB } & Body mass index & 0.015 & 0.003 & 0.283 & 5.122 & 0.000 \\
\hline & Age & 0.003 & 0.001 & 0.245 & 4.418 & 0.000 \\
\hline & Alcohol consumption & 0.035 & 0.015 & 0.132 & 2.384 & 0.018 \\
\hline \multirow[t]{2}{*}{ ApoAl/ApoB } & Body mass index & -0.036 & 0.008 & -0.272 & -4.721 & 0.000 \\
\hline & Alcohol consumption & 0.161 & 0.039 & 0.240 & 4.150 & 0.000 \\
\hline \multicolumn{7}{|l|}{ Han/female } \\
\hline \multirow[t]{2}{*}{$\mathrm{TC}$} & Age & 0.020 & 0.004 & 0.292 & 5.413 & 0.000 \\
\hline & Body mass index & 0.074 & 0.017 & 0.232 & 4.308 & 0.000 \\
\hline TG & Body mass index & 0.057 & 0.016 & 0.196 & 3.499 & 0.001 \\
\hline $\mathrm{HDL}-\mathrm{C}$ & Cigarette smoking & 0.479 & 0.198 & 0.137 & 2.425 & 0.016 \\
\hline \multirow[t]{2}{*}{ LDL-C } & Age & 0.016 & 0.003 & 0.299 & 5.612 & 0.000 \\
\hline & Body mass index & 0.066 & 0.014 & 0.254 & 4.769 & 0.000 \\
\hline \multirow[t]{2}{*}{ ApoAl } & Age & 0.004 & 0.001 & 0.209 & 3.761 & 0.000 \\
\hline & Cigarette smoking & 0.316 & 0.124 & 0.142 & 2.559 & 0.011 \\
\hline \multirow[t]{2}{*}{ ApoB } & Body mass index & 0.022 & 0.003 & 0.344 & 6.530 & 0.000 \\
\hline & Age & 0.003 & 0.001 & 0.223 & 4.228 & 0.000 \\
\hline \multirow[t]{2}{*}{ ApoAl/ApoB } & Body mass index & -0.042 & 0.010 & -0.236 & -4.335 & 0.000 \\
\hline & Cigarette smoking & 0.883 & 0.232 & 0.207 & 3.810 & 0.000 \\
\hline
\end{tabular}

TC, total cholesterol; TG, triglyceride; HDL-C, high-density lipoprotein cholesterol; LDL-C, low-density lipoprotein cholesterol; ApoAl, apolipoprotein Al; ApoB, apolipoprotein B.

as in the animals. Furthermore, a recent research reported that the rs5888 variant in the SCARB1 affected SCARB1 RNA secondary structure, protein translation, and was significantly associated with reduced SCARB1 protein expression and function in vitro [34]. In the present research, however, we showed that the subjects with TT genotype in Bai Ku Yao had lower HDL-C and ApoAI levels in males than the subjects with $\mathrm{CC}$ or $\mathrm{CT}$ genotype, and the $\mathrm{T}$ allele carriers had higher $\mathrm{TC}$, LDL-C and ApoB levels in females than the T allele noncarriers. The participants with TT genotype in Han also had a lower tendency of HDL-C and ApoAI levels in males than the participants with $\mathrm{CC}$ or $\mathrm{CT}$ genotype, but the difference did not reach statistically significant. The association of serum HDL-C and ApoAI levels and genotypes was confirmed by the multiple linear regression analysis in both ethnic groups. It is difficult to explain these contradictory findings. The possible reasons may be as follows. Firstly, in our study the frequency of $\mathrm{C}$ allele was $78.3 \%$ in Bai $\mathrm{Ku}$ Yao and $73.7 \%$ in Han. In white populations, however, the $\mathrm{C}$ allelic frequency of SCARB1 rs5888 was varied from $40 \%$ to $60 \%$, which suggests that our study populations had different genetic background from white populations. Moreover, the $\mathrm{C}-\mathrm{T}$ change at exon 8 did not affect the amino acid sequence of the protein, the SNP might be in linkage disequilibrium with a functional mutation in the SCARB1 gene, or alternatively with another nearby functional variant at the chromosomal region of 12q24 where several other candidate genes involved in lipid metabolism have been localized (i.e. ACACB, PLA2, CLTA, MVK-MMAB, ACADS, and TCF1) [20,23]. Thus, our findings contradict with previous papers may attribute to different functional mutation of the SCARB1 rs5888 or to be in linkage disequibibrium with other SNPs. Secondly, it might because of difference in study designs, sample size, as well as gene-enviromental interactions. Lastly, the size of our study population is a bit small, and the number of subjects with TT genotype in both ethnic groups is also small, which might not have had the power to detect the association of TT genotype and serum lipid levels.

In addition to the influence of genetic factors, environmental factors also play an important role in determining serum lipid levels $[25,26]$. In the present study, we also found that serum lipid parameters were correlated with several environmental factors. Although Bai Ku Yao and Han reside in the same region, the diet and lifestyle were significant difference between the two ethnic groups. For the Bai $\mathrm{Ku}$ Yao population, corn was the staple food and rice, soy, buckwheat, sweet potato, and pumpkin products were the subsidiary foods. Approximately $90 \%$ of the beverages were corn wine and rum. The alcohol content is about $15 \%(\mathrm{v} / \mathrm{v})$. They are also accustomed to drink Hempseed soup. In contrast, rice was the staple food and corn, broomcorn, potato, and taro products were the subsidiary foods in the Han population. About $90 \%$ of the beverage was rice wine. 
Table $\mathbf{5}$ Correlative factors for serum lipid parameters

\begin{tabular}{|c|c|c|c|c|c|c|}
\hline Lipid parameter & Relative factor & Unstandardized coefficient & Std. error & Standardized coefficient & $t$ & $P$ \\
\hline \multicolumn{7}{|l|}{ Both Yao and Han } \\
\hline \multirow[t]{5}{*}{ TC } & Age & 0.011 & 0.002 & 0.181 & 6.402 & 0.000 \\
\hline & Body mass index & 0.059 & 0.009 & 0.180 & 6.419 & 0.000 \\
\hline & Ethnic group & 0.343 & 0.054 & 0.177 & 6.368 & 0.000 \\
\hline & Diastolic blood pressure & 0.010 & 0.003 & 0.115 & 3.850 & 0.000 \\
\hline & Alcohol consumption & 0.089 & 0.039 & 0.064 & 2.285 & 0.022 \\
\hline \multirow[t]{4}{*}{ TG } & Body mass index & 0.078 & 0.010 & 0.211 & 7.567 & 0.000 \\
\hline & Sex & -0.257 & 0.071 & -0.117 & -3.631 & 0.000 \\
\hline & Alcohol consumption & 0.207 & 0.052 & 0.133 & 3.981 & 0.000 \\
\hline & Ethnic group & 0.167 & 0.063 & 0.076 & 2.657 & 0.008 \\
\hline \multirow[t]{6}{*}{$\mathrm{HDL}-\mathrm{C}$} & Age & 0.005 & 0.001 & 0.174 & 6.163 & 0.000 \\
\hline & Alcohol consumption & 0.172 & 0.021 & 0.275 & 8.177 & 0.000 \\
\hline & Sex & 0.155 & 0.029 & 0.176 & 5.435 & 0.000 \\
\hline & Ethnic group & 0.115 & 0.025 & 0.130 & 4.548 & 0.000 \\
\hline & Body mass index & -0.018 & 0.004 & -0.119 & -4.252 & 0.000 \\
\hline & Genotype & -0.049 & 0.020 & -0.066 & -2.389 & 0.017 \\
\hline \multirow[t]{5}{*}{ LDL-C } & Body mass index & 0.051 & 0.008 & 0.193 & 6.678 & 0.000 \\
\hline & Age & 0.008 & 0.001 & 0.167 & 5.731 & 0.000 \\
\hline & Ethnic group & 0.103 & 0.045 & 0.066 & 2.313 & 0.021 \\
\hline & Diastolic blood pressure & 0.007 & 0.002 & 0.089 & 2.894 & 0.004 \\
\hline & Alcohol consumption & -0.065 & 0.032 & -0.059 & -2.029 & 0.043 \\
\hline \multirow[t]{5}{*}{ ApoAl } & Alcohol consumption & 0.156 & 0.015 & 0.346 & 10.638 & 0.000 \\
\hline & Age & 0.004 & 0.001 & 0.194 & 7.111 & 0.000 \\
\hline & Ethnic group & 0.086 & 0.018 & 0.136 & 4.852 & 0.000 \\
\hline & Genotype & -0.132 & 0.039 & -0.092 & -3.420 & 0.001 \\
\hline & Sex & 0.065 & 0.020 & 0.103 & 3.285 & 0.001 \\
\hline \multirow[t]{4}{*}{ ApoB } & Body mass index & 0.018 & 0.002 & 0.249 & 8.686 & 0.000 \\
\hline & Age & 0.002 & 0.000 & 0.148 & 5.150 & 0.000 \\
\hline & Ethnic group & -0.038 & 0.012 & -0.089 & -3.237 & 0.001 \\
\hline & Diastolic blood pressure & 0.002 & 0.001 & 0.080 & 2.669 & 0.008 \\
\hline \multirow[t]{4}{*}{ ApoAl/ApoB } & Alcohol consumption & 0.267 & 0.031 & 0.286 & 8.523 & 0.000 \\
\hline & Body mass index & -0.042 & 0.006 & -0.190 & -6.777 & 0.000 \\
\hline & Ethnic group & 0.142 & 0.038 & 0.108 & 3.755 & 0.000 \\
\hline & Sex & 0.105 & 0.043 & 0.080 & 2.458 & 0.014 \\
\hline \multicolumn{7}{|l|}{ Bai Ku Yao } \\
\hline \multirow[t]{3}{*}{ TC } & Body mass index & 0.067 & 0.016 & 0.172 & 4.214 & 0.000 \\
\hline & Age & 0.007 & 0.002 & 0.109 & 2.655 & 0.008 \\
\hline & Diastolic blood pressure & 0.008 & 0.004 & 0.083 & 1.972 & 0.049 \\
\hline \multirow[t]{4}{*}{ TG } & Alcohol consumption & 0.258 & 0.067 & 0.198 & 3.872 & 0.000 \\
\hline & Body mass index & 0.054 & 0.016 & 0.132 & 3.302 & 0.001 \\
\hline & Sex & -0.330 & 0.106 & -0.169 & -3.116 & 0.002 \\
\hline & Cigarette smoking & -0.153 & 0.070 & -0.120 & -2.185 & 0.029 \\
\hline \multirow[t]{2}{*}{$\mathrm{HDL}-\mathrm{C}$} & Alcohol consumption & 0.126 & 0.022 & 0.228 & 5.777 & 0.000 \\
\hline & Age & 0.004 & 0.001 & 0.142 & 3.586 & 0.000 \\
\hline
\end{tabular}


Table 5 Correlative factors for serum lipid parameters (Continued)

\begin{tabular}{|c|c|c|c|c|c|c|}
\hline & Genotype & -0.245 & 0.090 & -0.106 & -2.714 & 0.007 \\
\hline \multirow[t]{2}{*}{ LDL-C } & Body mass index & 0.062 & 0.013 & 0.194 & 4.855 & 0.000 \\
\hline & Age & 0.005 & 0.002 & 0.098 & 2.437 & 0.015 \\
\hline \multirow[t]{3}{*}{ ApoAl } & Alcohol consumption & 0.143 & 0.016 & 0.333 & 8.708 & 0.000 \\
\hline & Age & 0.003 & 0.001 & 0.140 & 3.655 & 0.000 \\
\hline & Genotype & -0.177 & 0.068 & -0.099 & -2.611 & 0.009 \\
\hline \multirow[t]{4}{*}{ ApoB } & Body mass index & 0.019 & 0.004 & 0.205 & 5.064 & 0.000 \\
\hline & Age & 0.002 & 0.001 & 0.104 & 2.564 & 0.011 \\
\hline & Alcohol consumption & -0.032 & 0.012 & -0.107 & -2.611 & 0.009 \\
\hline & Diastolic blood pressure & 0.002 & 0.001 & 0.097 & 2.306 & 0.021 \\
\hline \multirow[t]{2}{*}{ ApoAl/ApoB } & Alcohol consumption & 0.311 & 0.039 & 0.309 & 7.940 & 0.000 \\
\hline & Body mass index & -0.044 & 0.012 & -0.137 & -3.522 & 0.000 \\
\hline \multicolumn{7}{|l|}{ Han Chinese } \\
\hline \multirow[t]{4}{*}{ TC } & Age & 0.016 & 0.002 & 0.260 & 6.443 & 0.000 \\
\hline & Body mass index & 0.050 & 0.011 & 0.174 & 4.374 & 0.000 \\
\hline & Diastolic blood pressure & 0.012 & 0.004 & 0.142 & 3.341 & 0.001 \\
\hline & Alcohol consumption & 0.164 & 0.061 & 0.101 & 2.697 & 0.007 \\
\hline \multirow[t]{2}{*}{ TG } & Body mass index & 0.094 & 0.013 & 0.270 & 6.949 & 0.000 \\
\hline & Cigarette smoking & 0.357 & 0.063 & 0.221 & 5.697 & 0.000 \\
\hline \multirow[t]{5}{*}{$\mathrm{HDL}-\mathrm{C}$} & Age & 0.006 & 0.001 & 0.219 & 5.533 & 0.000 \\
\hline & Sex & 0.244 & 0.040 & 0.264 & 6.074 & 0.000 \\
\hline & Alcohol consumption & 0.190 & 0.033 & 0.250 & 5.702 & 0.000 \\
\hline & Body mass index & -0.022 & 0.005 & -0.163 & -4.119 & 0.000 \\
\hline & Genotype & -0.075 & 0.028 & -0.101 & -2.635 & 0.009 \\
\hline \multirow[t]{3}{*}{ LDL-C } & Age & 0.012 & 0.002 & 0.245 & 5.873 & 0.000 \\
\hline & Body mass index & 0.043 & 0.009 & 0.186 & 4.533 & 0.000 \\
\hline & Diastolic blood pressure & 0.006 & 0.003 & 0.090 & 2.062 & 0.040 \\
\hline \multirow[t]{4}{*}{ ApoAl } & Age & 0.005 & 0.001 & 0.251 & 6.600 & 0.000 \\
\hline & Alcohol consumption & 0.165 & 0.022 & 0.326 & 7.621 & 0.000 \\
\hline & Sex & 0.134 & 0.026 & 0.217 & 5.096 & 0.000 \\
\hline & Genotype & -0.037 & 0.019 & -0.074 & -1.979 & 0.048 \\
\hline \multirow[t]{3}{*}{ ApoB } & Body mass index & 0.018 & 0.002 & 0.323 & 8.524 & 0.000 \\
\hline & Age & 0.003 & 0.000 & 0.228 & 5.967 & 0.000 \\
\hline & Cigarette smoking & 0.028 & 0.010 & 0.105 & 2.807 & 0.005 \\
\hline \multirow[t]{3}{*}{ ApoAl/ApoB } & Body mass index & -0.039 & 0.006 & -0.256 & -6.450 & 0.000 \\
\hline & Sex & 0.232 & 0.047 & 0.218 & 4.931 & 0.000 \\
\hline & Alcohol consumption & 0.184 & 0.039 & 0.211 & 4.724 & \\
\hline
\end{tabular}

TC, total cholesterol; TG, triglyceride; HDL-C, high-density lipoprotein cholesterol; LDL-C, low-density lipoprotein cholesterol; ApoAl, apolipoprotein Al; ApoB, apolipoprotein B.

The content of alcohol is about $30 \%(\mathrm{v} / \mathrm{v})$. These differences in diet and lifestyle could partly account for the differences in serum lipid profiles between the two ethnic groups. Corn contains abundant dietary fiber and plant protein [35]. Consumption of dietary fiber, specifically the soluble type, such as pectins and guar gum can decrease serum TC levels [36,37]. Plant protein might promote the transportation and excretion of free cholesterol. Dietary soy protein has well-documented beneficial effects on serum lipid concentrations $[38,39]$. Buckwheat protein products have a potent hypocholesterolemic activity [40,41]. Ludvik et al. [42] found that ingestion of 
$4 \mathrm{~g} /$ day caiapo (the extract of white-skinned sweet potato) for 6 weeks reduced TC and LDL-C in type 2 diabetic patients previously treated by diet alone. Studies have demonstrated that pumpkin is a useful therapy for hypercholesterolemia through reducing oxidative stress and cholesterol levels [43]. There are more than 29 fat soluble constituents in Hempseed, among which saturated and unsaturated fatty acid methyl esters account for $12.36 \%$ and $86.96 \%$; respectively [44]. Previous experimental and clinical studies have demonstrated that Hempseed or Hempseed oil can decrease TC, TG and LDL-C levels, reduce atherogenic index, and increase HDL-C concentration $[25,26,45]$.

\section{Conclusion}

The present study shows that the frequency of $\mathrm{T}$ allele of SCARB1 rs5888 SNP is lower in Bai Ku Yao than in Han Chinese. The subjects with TT genotype in Bai Ku Yao had lower HDL-C and ApoAI levels in males than the subjects with $\mathrm{CC}$ or $\mathrm{CT}$ genotype, and the $\mathrm{T}$ allele carriers had higher TC, LDL-C and ApoB levels in females than the $\mathrm{T}$ allele noncarriers. The participants with TT genotype in Han also had a lower tendency of HDL-C and ApoAI levels in males than the participants with $\mathrm{CC}$ or CT genotype, but the difference did not reach statistically significant. The levels of HDL-C and ApoAI were correlated with genotypes in the both ethnic groups. These results suggest that the differences in serum lipid levels between the two enthnic groups might partially attribute to the differences in the SCARB1 rs5888 SNP and several environmental factors.

\section{Competing interests}

The authors declare that they have no competing interests.

\section{Acknowledgments}

This study was supported by the National Natural Science Foundation of China (No: 30660061)

\section{Author details}

'Department of Cardiology, Institute of Cardiovascular Diseases, the First Affiliated Hospital, Guangxi Medical University, 22 Shuangyong Road, Nanning, 530021Guangxi, People's Republic of China. ${ }^{2}$ Department of Pathophysiology, School of Premedical Sciences, Guangxi Medical University, Nanning, 530021Guangxi, People's Republic of China.

\section{Authors' contributions}

DFW participated in the design, undertook genotyping, and drafted the manuscript. RXY conceived the study, participated in the design, carried out the epidemiological survey, collected the samples, and helped to draft the manuscript. XJH, LHHA, XLC, LM, QL and TTY collaborated to the genotyping. JZW and SLP carried out the epidemiological survey and collected the samples. All authors read and approved the final manuscript.

Received: 16 January 2012 Accepted: 14 May 2012

Published: 14 May 2012

\section{References}

1. Natarajan P, Ray KK, Cannon CP: High-density lipoprotein and coronary heart disease: current and future therapies. J Am Coll Cardiol 2010, 55:1283-99.
2. Genest JJ Jr, Martin-Munley SS, McNamara JR, Ordovas JM, Jenner J, Myers RH, Silberman SR, Wilson PW, Salem DN, Schaefer EJ: Familial lipoprotein disorders in patients with premature coronary artery disease. Circulation 1992, 85:2025-33.

3. Ballantyne CM, Olsson AG, Cook TJ, Mercuri MF, Pedersen TR, Kjekshus J: Influence of low high-density lipoprotein cholesterol and elevated triglyceride on coronary heart disease events and response to simvastatin therapy in 4 S. Circulation 2001, 104:3046-51.

4. Linsel-Nitschke P, Tall AR: HDL as a target in the treatment of atherosclerotic cardiovascular disease. Nat Rev Drug Discov 2005, 4:193-205.

5. Wilson PW: High-density lipoprotein, low-density lipoprotein and coronary artery disease. Am J Cardiol 1990, 66:7A-10A.

6. Heller DA, de Faire U, Pedersen NL, Dahlen G, McClearn GE: Genetic and environmental influences on serum lipid levels in twins. $N$ Engl J Med 1993, 328:1150-6.

7. Chen SN, Cilingiroglu M, Todd J, Lombardi R, Willerson JT, Gotto AM Jr, Ballantyne CM, Marian AJ: Candidate genetic analysis of plasma highdensity lipoprotein-cholesterol and severity of coronary atherosclerosis. BMC Med Genet 2009, 10:111.

8. Boes E, Coassin S, Kollerits B, Heid IM, Kronenberg F: Geneticepidemiological evidence on genes associated with $\mathrm{HDL}$ cholesterol levels: a systematic in-depth review. Exp Gerontol 2008, 44:136-60.

9. Acton S, Rigotti A, Landschulz KT, Xu S, Hobbs HH, Krieger M: Identification of scavenger receptor SR-BI as a high density lipoprotein receptor. Science 1996, 271:518-20.

10. Kozarsky KF, Donahee MH, Rigotti A, lqbal SN, Edelman ER, Krieger M: Overexpression of the HDL receptor SR-BI alters plasma HDL and bile cholesterol levels. Nature 1997, 387:414-7.

11. Rigotti A, Trigatti BL, Penman M, Rayburn H, Herz J, Krieger M: A targeted mutation in the murine gene encoding the high density lipoprotein (HDL) receptor scavenger receptor class B type I reveals its key role in HDL metabolism. Proc Natl Acad Sci USA 1997, 94:12610-5.

12. Varban ML, Rinninger F, Wang N, Fairchild-Huntress $V$, Dunmore JH, Fang $Q$, Gosselin ML, Dixon KL, Deeds JD, Acton SL, Tall AR, Huszar D: Targeted mutation reveals a central role for SR-BI in hepatic selective uptake of high density lipoprotein cholesterol. Proc Natl Acad Sci USA 1998, 95:4619-24.

13. Calvo D, Gomez-Coronado D, Lasuncion MA, Vega MA: CLA-1 is an $85-k D$ plasma membrane glycoprotein that acts as a high-affinity receptor for both native (HDL, LDL, and VLDL) and modified (OxLDL and ACLDL) lipoproteins. Arterioscler Thromb Vasc Biol 1997, 17:2341-9.

14. Swarnakar S, Temel RE, Connelly MA, Azhar S, Williams DL: Scavenger receptor class $B$, type I, mediates selective uptake of low density lipoprotein cholesteryl ester. J Biol Chem 1999, 274:29733-9.

15. Wang N, Arai T, Ji Y, Rinninger F, Tall AR: Liver-specific overexpression of scavenger receptor $\mathrm{BI}$ decreases levels of very low density lipoprotein $A p o B$, low density lipoprotein $A p o B$, and high density lipoprotein in transgenic mice. J Biol Chem 1998, 273:32920-6.

16. Ueda Y, Royer L, Gong E, Zhang J, Cooper PN, Francone O, Rubin EM: Lower plasma levels and accelerated clearance of high density lipoprotein (HDL) and non-HDL cholesterol in scavenger receptor class B type I transgenic mice. J Biol Chem 1999, 274:7165-71.

17. Huszar D, Varban ML, Rinninger F, Feeley R, Arai T, Fairchild-Huntress V, Donovan MJ, Tall AR: Increased LDL cholesterol and atherosclerosis in LDL receptor-deficient mice with attenuated expression of scavenger receptor B1. Arterioscler Thromb Vasc Biol 2000, 20:1068-73.

18. Feitosa ME, Rice T, Borecki IB, Rankinen T, Leon AS, Skinner JS, Despres JP, Blangero J, Bouchard C, Rao DC: Pleiotropic QTL on chromosome 12q23q24 influences triglyceride and high-density lipoprotein cholesterol levels: the HERITAGE family study. Hum Biol 2006, 78:317-27.

19. Roberts CG, Shen H, Mitchell BD, Damcott CM, Shuldiner AR, Rodriguez A: Variants in scavenger receptor class B type I gene are associated with HDL cholesterol levels in younger women. Hum Hered 2007, 64:107-13.

20. Acton S, Osgood D, Donoghue M, Corella D, Pocovi M, Cenarro A, Mozas P, Keilty J, Squazzo S, Woolf EA, Ordovas JM: Association of polymorphisms at the SR-BI gene locus with plasma lipid levels and body mass index in a white population. Arterioscler Thromb Vasc Biol 1999, 19:1734-43.

21. Morabia A, Ross BM, Costanza MC, Cayanis E, Flaherty MS, Alvin GB, Das K, James R, Yang AS, Evagrafov O, Gilliam TC: Population-based study of SRBI genetic variation and lipid profile. Atherosclerosis 2004, 175:159-68. 
22. McCarthy JJ, Lewitzky S, Reeves C, Permutt A, Glaser B, Groop LC, Lehner T, Meyer JM: Polymorphisms of the HDL receptor gene associated with $\mathrm{HDL}$ cholesterol levels in diabetic kindred from three populations. Hum Hered 2003, 55:163-70.

23. Osgood D, Corella D, Demissie S, Cupples LA, Wilson PWF, Meigs JB, Schaefer EJ, Coltell O, Ordovas JM: Genetic variation at the scavenger receptor class B type I gene locus determines plasma lipoprotein concentrations and particle size and interacts with type 2 diabetes: the framingham study. J Clin Endocrinol Metab 2003, 88:2869-79.

24. Hong SH, Kim YR, Yoon YM, Min WK, Chun SI, Kim JQ: Association between Haelll polymorphism of scavenger receptor class B type I gene and plasma HDL-cholesterol concentration. Ann Clin Biochem 2002, 39:478-81.

25. Ruixing Y, Qiming F, Dezhai Y, Shuquan L, Weixiong L, Shangling P, Hai W, Yongzhong $Y$, Feng $H$, Shuming Q: Comparison of demography, diet, lifestyle, and serum lipid levels between the Guangxi Bai Ku Yao and Han populations. J Lipid Res 2007, 48:2673-81.

26. Ruixing $Y$, Dezhai $Y$, Shuquan $L$, Yuming $C$, Hanjun $Y$, Qiming F, Shangling $P$, Weixiong $L$, Jing $T$, Yiyang $L$ : Hyperlipidaemia and its risk factors in the Guangxi Bai Ku Yao and Han populations. Public Health Nutr 2009, 12:816-24.

27. People's Republic of China-United States Cardiovascular and Cardiopulmonary Epidemiology Research Group: An epidemiological study of cardiovascular and cardiopulmonary disease risk factors in four populations in the People's Republic of China. Baseline report from the P.R.C.-U.S.A. Collaborative Study. Circulation 1992, 85:1083-96.

28. Wu DF, Yin RX, Aung LH, Hu XJ, Cao XL, Miao L, Li Q, Yan TT, Wu JZ, Pan SL: Polymorphism of rs1044925 in the acyl-CoA:cholesterol acyltransferase-1 gene and serum lipid levels in the Guangxi Bai Ku Yao and Han populations. Lipids Health Dis 2010, 9:139.

29. Ruixing $Y$, Weixiong L, Hanjun $Y$, Dezhai $Y$, Shuquan L, Shangling P, Qiming F, Jinzhen W, Jianting G, Yaju D: Diet, lifestyle, and blood pressure of the middle-aged and elderly in the Guangxi Bai Ku Yao and Han populations. Am J Hypertens 2008, 21:382-7.

30. McCarthy JJ, Lehner T, Reeves C, Moliterno DJ, Newby LK, Rogers WJ, Topol EJ: Association of genetic variants in the HDL receptor, SR-B1, with abnormal lipids in women with coronary artery disease. J Med Genet 2003, 40:453-8.

31. Tai ES, Adiconis X, Ordovas JM, Carmena-Ramon R, Real J, Corella D, Ascaso J, Carmena R: Polymorphisms at the SRBI locus are associated with lipoprotein levels in subjects with heterozygous familial hypercholesterolemia. Clin Genet 2003, 63:53-8.

32. Hsu LA, Ko YL, Wu S, Teng MS, Peng TY, Chen CF, Chen CF, Lee YS: Association between a novel 11-base pair deletion mutation in the promoter region of the scavenger receptor class B type I gene and plasma HDL cholesterol levels in Taiwanese Chinese. Arterioscler Thromb Vasc Biol 2003, 23:1869-74.

33. West M, Greason E, Kolmakova A, Jahangiri A, Asztalos B, Pollin TI, Rodriguez A: Scavenger receptor class B type I protein as an independent predictor of high-density lipoprotein cholesterol levels in subjects with hyperalphalipoproteinemia. J Clin Endocrinol Metab 2009, 94:1451-57.

34. Constantineau J, Greason E, West M, Filbin M, Kieft JS, Carletti MZ, Christenson LK, Rodriguez A: A synonymous variant in scavenge receptor, class $B$, type I gene is associated with lower SR-BI protein expression and function. Atherosclerosis 2010, 210:177-82.

35. Dong W, Ma X, Zhang D, Yu S: Effect of maize embryo on delaying aging. Food Sci 2002, 23:95-97.

36. Lairon D: Dietary fibres: effects on lipid metabolism and mechanisms of action. Eur J Clin Nutr 1996, 50:125-33.

37. Jenkins DJ, Kendall CW, Axelsen M, Augustin LS, Vuksan V: Viscous and nonviscous fibres, nonabsorbable and low glycaemic index carbohydrates, blood lipids and coronary heart disease. Curr Opin Lipidol 2000, 11:49-56.

38. Weggemans RM, Trautwein EA: Relation between soy-associated isoflavones and LDL and HDL cholesterol concentrations in humans: a meta-analysis. Eur J Clin Nutr 2003, 57:940-6.

39. Zhan S, Ho SC: Meta-analysis of the effects of soy protein containing isoflavones on the lipid profile. Am J Clin Nutr 2005, 81:397-408.

40. Tomotake H, Shimaoka I, Kayashita J, Yokoyama F, Nakajoh M, Kato N: Stronger suppression of plasma cholesterol and enhancement of the fecal excretion of steroids by a buckwheat protein product than by a soy protein isolate in rats fed on a cholesterol-free diet. Biosci Biotechnol Biochem 2001, 65:1412-4.
41. Kayashita J, Shimaoka I, Nakajoh M, Yamazaki M, Kato N: Consumption of buckwheat protein lowers plasma cholesterol and raises fecal neutral sterols in cholesterol-Fed rats because of its low digestibility. J Nutr 1997, 127:1395-400

42. Ludvik BH, Mahdjoobian K, WaldhaeusI W, Hofer A, Prager R, Kautzky-Willer A, Pacini G: The effect of Ipomoea batatas (Caiapo) on glucose metabolism and serum cholesterol in patients with type 2 diabetes: a randomized study. Diabetes Care 2002, 25:239-40.

43. Adaramoye OA, Achem J, Akintayo OO, Fafunso MA: Hypolipidemic effect of Telfairia occidentalis (fluted pumpkin) in rats fed a cholesterol-rich diet. J Med Food 2007, 10:330-6.

44. Ross SA, Mehmedic Z, Murphy TP, Elsohly MA: GC-MS analysis of the total delta9-THC content of both drug- and fiber-type cannabis seeds. J Anal Toxicol 2000, 24:715-7.

45. Schwab US, Callaway JC, Erkkila AT, Gynther J, Uusitupa MI, Jarvinen T: Effects of hempseed and flaxseed oils on the profile of serum lipids, serum total and lipoprotein lipid concentrations and haemostatic factors. Eur J Nutr 2006, 45:470-7.

doi:10.1186/1476-511X-11-50

Cite this article as: Wu et al:: Association of rs5888 SNP in the scavenger receptor class B type 1 gene and serum lipid levels. Lipids in Health and Disease 2012 11:50.

\section{Submit your next manuscript to BioMed Central and take full advantage of:}

- Convenient online submission

- Thorough peer review

- No space constraints or color figure charges

- Immediate publication on acceptance

- Inclusion in PubMed, CAS, Scopus and Google Scholar

- Research which is freely available for redistribution 